\title{
The effects of oleaster flour, active gluten \\ and sucrose replacement with potassium acesulfame and isomalt on the qualitative properties of functional sponge cakes
}

\author{
Efeitos de farinha de oleaster, glúten ativo e substituição de \\ sacarose com acessulfame de potássio e isomalte nas \\ propriedades funcionais de bolo funcional
}

\author{
Samaneh Babashahi Kouhanestani ${ }^{1}$, Hajar Abbasi $^{1 *}$ (i), Nafiseh Zamindar ${ }^{1}$ \\ ${ }^{1}$ Department of Food Science and Technology, College of Agriculture and Natural Resources, Isfahan (Khorasgan) \\ Branch, Islamic Azad University, Isfahan - Iran \\ *Corresponding Author: Hajar Abbasi, Islamic Azad University, Isfahan (Khorasgan) Branch, College of \\ Agriculture and Natural Resources, Department of Food Science and Technology, Isfahan - Iran, e-mail: \\ H.Abbasi@Khuisf.ac.ir
}

Cite as: Kouhanestani, S. B., Abbasi, H., \& Zamindar, N. (2019). The effects of oleaster flour, active gluten and sucrose replacement with potassium acesulfame and isomalt on the qualitative properties of functional sponge cakes. Brazilian Journal of Food Technology, 22, e2018142. https://doi.org/10.1590/1981-6723.14218

\begin{abstract}
Oleaster (Elaeagnus angustifolia L.) is a fruit with special nutraceutical value which grows under a wide range of climatic conditions in Europe and Asia. In the present study, the effects of oleaster flour (15\%,30\% and $45 \%)$ and active gluten at ( 0 and $3 \%$ ) on the physical, chemical and sensory properties of sponge cakes were assessed. The best sample was selected based on the qualitative properties and compared with the control with respect to the staling rate and nutritional aspects. In order to decrease the calories, the sucrose content of the selected sample was replaced with potassium acesulfame and isomalt at the levels of $30 \%, 50 \%$ and $70 \%$. Oleaster flour increased the density but decreased the hardness and cohesiveness of the cake. Active gluten decreased the density and hardness but increased the cohesiveness and springiness. Considering the qualitative properties of the sponge cakes, the sample containing $30 \%$ oleaster flour and $3 \%$ gluten ( $30 \mathrm{OFG}$ ) was selected as the best. Replacement of the sucrose in 30 OFG increased the hardness, density, redness and yellowness of the crumb. With $30 \%$ sucrose replacement, the quality of the product was adequately maintained. The use of oleaster significantly increased the calcium, potassium, crude fibre, fat and total phenolic compound contents of the sponge cakes as compared to the control. The sample containing 30\% oleaster flour and 3\% gluten with 30\% sucrose replacement showed appropriate physicochemical, textural and sensory properties.
\end{abstract}

Keywords: Functional cake; Low calorie; Mineral; Nutritional value; Sweetener; Textural properties.

\section{Resumo}

Oleaster (Elaeagnus angustifolia L.) é uma fruta com valor nutracêutico especial, que cresce em uma ampla faixa de condições climáticas na Europa e na Ásia. No estudo atual, os efeitos da farinha de oleaster (15\%, 30\% e 45\%) e de glúten ativo ( 0 e $3 \%$ ) nas propriedades físicas, químicas e sensoriais de bolos tipo esponja foram avaliados. A melhor 
amostra foi selecionada baseando-se nas suas propriedades qualitativas e comparando-se com o controle em relação à taxa de endurecimento e aos aspetos nutricionais. Para diminuir as calorias, o conteúdo de sacarose da amostra selecionada foi substituído por acessulfame de potássio e isomalte nos níveis de $30 \%, 50 \%$ e $70 \%$. A farinha de oleaster aumentou a densidade do bolo, mas diminuiu a dureza e a coesão. O glúten ativo diminuiu a densidade e a dureza, mas aumentou a coesão e a elasticidade. Considerando as propriedades qualitativas dos bolos tipo esponja, a amostra contendo $30 \%$ de farinha de oleaster e $3 \%$ de glúten ativo (30 OFG) foi selecionada como a melhor. A substituição da sacarose em 30 OFG aumentou a dureza, a densidade e as cores vermelho e amarelo do miolo, mas, com substituição de $30 \%$ da sacarose, a qualidade do produto foi mantida adequadamente. O uso de oleaster aumentou significativamente os conteúdos de cálcio, potássio, fibra bruta, gordura e compostos fenólicos totais. A amostra contendo $30 \%$ de farinha de oleaster e $3 \%$ de glúten com substituição de $30 \%$ da sacarose apresentou propriedades físico-químicas, de textura e sensoriais apropriadas.

Palavras-chave: Bolo funcional; Baixa caloria; Mineral; Valor nutricional; Adoçante; Propriedades texturais.

\section{Introduction}

In recent decades, changing human life-styles and dietary patterns have increase obesity, chronic diseases and heart diseases (Kendall et al., 2010). Therefore, producing healthier, low calorie food products has become an important issue in the food industry. The consumption of fibrous compounds, natural sweeteners, non-metabolizable sweeteners (e.g., potassium acesulfame (Ace K)) or low absorbent sweeteners (e.g., isomalt) is a suitable way of producing healthier foods (Lipinski \& Hanger, 2001; Grembecka, 2015).

Due to their palatability, feasible price and high consumption, cereal products are considered as appropriate carriers of bioactive compounds and dietary fibres in the human diet (Lebesi \& Tzia, 2011). Sponge cakes are one of the most consumed confectioneries made from refined flour, oil, egg and sugar (Farzi et al., 2015). Although wheat is relatively rich in nutritional value, refined flour and products made from it such as confectionery products, have nutritional deficiencies due to the removal of trace nutrient elements from the outer layer during the milling process (Pourafshar et al., 2015; Moza \& Gujral, 2017).

The oleaster tree grows in a wide range of climatic conditions in various regions of Europe and in parts of Central Asia, including Iran (Sahan et al., 2013). The reddish-brown Oleaster fruit (Elaeagnus angustifolia L.), which is about 9-12 $\mathrm{mm}$ long and 6-10 $\mathrm{mm}$ wide has a special nutritional value (Sarraf et al., 2017). Glucose and fructose are the two dominant sugars in the fruit. Due to the presence of seven types of phenolic acid (Ayaz \& Bertoft, 2001) and numerous flavonoid compounds (Abizov et al., 2008), it has been introduced as a useful natural antioxidant source. Significant amounts of other useful nutritional compounds such as proteins, vitamins (tocopherol, carotene, vitamin $\mathrm{C}$ and thiamine) and minerals (calcium, magnesium, potassium, iron) have been identified in this fruit. No toxic substance has been identified in the oleaster fruit and its consumption in the fields of medical, pharmaceutical and food science has been approved in both Asia and Europe (Çakmakçı et al., 2015). In Turkish traditional medicine, the oleaster fruit is consumed as a nutritious fruit with a fever-reducing component, and moreover its consumption is recommended for people with kidney disorders (Gürbüz et al., 2003; Çakmakçı et al., 2015). In Iranian traditional medicine, it is prescribed for patients with rheumatoid arthritis due to its anti-nociceptive and anti-inflammatory effects (Ramezani et al., 2001) and also in the control of nausea (Hosseinzadeh et al., 2003).

Due to its floury structure and its high nutritional and pharmaceutical value, the oleaster fruit can be used as a functional component in the food industry (Çakmakçı et al., 2015). Thus Sarraf et al. (2017) replaced 3, $6 \%, 9 \%, 12 \%$ and $15 \%$ of wheat flour with oleaster flour in a doughnut formulation and reported that the fat, ash and fibre contents of the product increased with increasing substitution level. Öztürk et al. (2018) studied the effect of adding $1 \%$ and $2 \%$ of oleaster flour on the quality characteristics of set yoghurt and showed that with $2 \%$ unpeeled oleaster flour, product syneresis was reduced, and that the scavenging activities and 
functional and textural properties were improved. Although there are some studies about the use of oleaster flour as an enrichment compound, the authors found no studies on its use at high replacement levels in functional bakery products, considering the need to reduce its adverse effects on the technological and qualitative properties of the products.

The aim of this study was to design low calorie enriched sponge cakes with the addition of oleaster flour and a combination of ace $\mathrm{k}$ - isomalt and gluten in order to minimize the negative effects caused by replacing the wheat flour. The study consisted of two steps: 1) assessing the effect of oleaster flour on the qualitative and nutritional characteristics of sponge cakes. In this context, considering the role of gluten on the rheological properties of cake, the effect of active gluten powder as an improving agent of the qualitative characteristics, was also assessed; and 2) after selecting the best sample from step one, assessing the effect of the partial replacement of the sucrose with Ace $\mathrm{K}$ and isomalt, on the quality of the selected sample.

\section{Material and methods}

Wheat flour (Atlas flour, Iran), sugar (NaghsheJahan, Iran), soybean oil (Pamchal, Iran), egg (Talavang, Iran), milk powder (Palood, Iran), vanilla and baking powder (Sahar, Iran) were purchased from local shops (Isfahan, Iran). The oleaster fruits (Elaeagnus angustifolia L.) came from the Khansar province (Isfahan, Iran) and were dried in a vacuum drying oven at $60^{\circ} \mathrm{C}$ and $45 \mathrm{~cm} \mathrm{Hg}$ (SH-Scientific, South Korea) to reach $12 \%$ moisture content. The mesocarp and pericarp were then milled in a stainless steel mixer (Artisam 5000, Iran) and sieved (mesh size 40). The active gluten powder (moisture $=10 \%$, protein $=82 \%$, ash $=0.3 \%, \mathrm{pH}=6.1$ and water absorption percentage $=1.6 \%$ ) was purchased from Shahdine Aran Co. (Isfahan, Iran) and the isomalt ST-PF (Particle size $<0.1 \mathrm{~mm}$, low hygroscopicity) and potassium acesulfame (Ace K) (white crystalline powder, very thermo stable, storage stable) were purchased from the Beneo Co. (Germany).

\subsection{Proximate compositions of the wheat and oleaster flours}

The wheat and oleaster flours were analysed according to the AACC methods for their ash (AACC 08-01), fat (AACC 30-25), protein (AACC 46-11A) and crude fibre contents (AACC23-10) (American Association of Cereal Chemists, 2000). The total phenolic compound content was determined according to the method proposed by Karp et al. (2017) with some modifications. One gram of sample was mixed with $10 \mathrm{~mL}$ double-distilled water and centrifuged $(2000 \mathrm{~g})$ for $10 \mathrm{~min}$ at $25^{\circ} \mathrm{C}$. A mixture of $0.5 \mathrm{~mL}$ supernatant, $5 \mathrm{~mL}$ of Folin-Ciocalteu reagent (1: 5) and $4 \mathrm{~mL}$ of sodium carbonate $(10 \% \mathrm{w} / \mathrm{w})$ was prepared and after 15 minutes at room temperature, the absorption was measured at $765 \mathrm{~nm}$ in a UV-Visible spectrophotometer (UV 2100, Unico, USA). The amount of total phenolic compounds was reported as mg gallic acid (GAE) per 100 grams of sample.

\subsection{Preparation of sponge cake}

The cake batter was prepared using the sugar-batter method, according to the contents shown in Table 1 . About 60 grams of batter was placed in a pan and baked in the oven for 20 minutes at $220^{\circ} \mathrm{C}$. After baking, the cakes were cooled for 45 minutes at ambient temperature, packed in polyethylene and stored at $23{ }^{\circ} \mathrm{C}$ for analysis.

A completely randomized design-factorial experiment was used. The variables were the oleaster replacement level (15\%,30\% and 45\%) and gluten level ( 0 and 3\%), based on the wheat flour content of the formulation. Seven samples including the control (100\% wheat flour), three sponge cakes with 15,30 and $45 \%$ of oleaster flour (15 OF, $30 \mathrm{OF}, 45 \mathrm{OF}$ ) and three samples with $15 \%, 30 \%, 45 \%$ of oleaster flour and $3 \%$ gluten ( $15 \mathrm{OFG}, 30 \mathrm{OFG}$ and $45 \mathrm{OFG}$ ) were considered. In the second step, $0,30 \%, 50 \%$ and $70 \%$ of the sucrose content of the selected sample from the first step was replaced with potassium acesulfame and isomalt. 
The effects of oleaster flour, active gluten and sucrose replacement with potassium acesulfame and isomalt on the qualitative properties of functional sponge cakes

Kouhanestani, S. B. et al.

Table 1. Ingredients (for the control sample) and preparation method of the sponge cake batter.

\begin{tabular}{ccc}
\hline Ingredients & Weight $\mathbf{( g )}$ & Procedure \\
\hline Soybean oil & 171.0 & mixed for 10 min. \\
Sugar & 216.0 & added in 4 portions and mixed for 5 min \\
\hline Egg & 216.0 & \\
\hline Wheat flour & 300.0 & mixed together and then added to the mixture \\
Baking powder & 6.0 & \\
Milk powder & 12.0 & mixed until the batter was smooth \\
Vanilla & 1.5 & . \\
\hline Water & 75.0 & \\
\hline
\end{tabular}

\subsection{Qualitative characteristics of the product}

The volume of the sponge cake was measured by the rapeseed displacement method and the apparent density calculated from the mass to volume ratio (Bigne et al., 2016).

The crumb texture was assessed 24 hours after baking using a Brookfield texture analyser (LFRA500) equipped with a cylindrical probe $(38.1 \mathrm{~mm}$ diameter). For this purpose, the crust was removed and a cylindrical sample $(2.5 \mathrm{~cm}$ height and $2 \mathrm{~cm}$ diameter) obtained from the crumb. In the texture profile analysis (TPA), the probe compressed the sample twice up to half its height at $1 \mathrm{~mm} / \mathrm{s}$ speed, with no delay between the first and second cycles (De la Hera et al., 2012).

The cake colour was assessed using the image processing method in a special optical box, according to the Salehi et al. (2016) method, with some modifications. For this purpose, the standard RAL colour cards, the crust and the crumb of the sample were photographed under the same conditions. The RGB indicators were obtained from the Adobe Photoshop version 8 and the RGB indexes of the sample were calibrated using a standard curve obtained from the RGB of the RAL cards, and converted into the CIE Lab system.

Considering the results of the analyses, the sample most similar to the control ( $100 \%$ wheat flour) in terms of the qualitative characteristics, was considered as the best sample in the first step.

\subsection{Replacement of sucrose with potassium acesulfame and isomalt}

The sucrose content of the sample selected in the first step was replaced by potassium acesulfame (200 times sweeter than sucrose) and isomalt. Three levels of sucrose replacement were used at $30 \%$ ( $0.15 \%$ potassium acesulfame and $29.85 \%$ isomalt $), 50 \%$ ( $0.25 \%$ potassium acesulfame and $49.75 \%$ isomalt) and $70 \%(0.35 \%$ potassium acesulfame and $69.65 \%$ isomalt $)$. The qualitative properties of the samples, such as apparent density, and the textural and colour properties were assessed according to the above-mentioned methods in 2.3. The sample selected in the first step was considered as the control in the second step.

\subsection{Sensory evaluation}

The organoleptic characteristics of the cakes (colour, odour, texture, taste, unpleasant aftertaste and overall acceptance) were assessed by fifteen semi-trained master's students of food science and technology using a 5-point hedonic scale $(1=$ disliked extremely; 2 = disliked; 3 = neither disliked nor liked; 4 = liked; 5 = liked extremely) (Kim et al., 2012). As to any unpleasant aftertaste, the sample with the least unpleasant aftertaste was scored with the highest grade and the one with the most unpleasant aftertaste was scored with the lowest grade. The sponge cakes were coded by random numbers and presented to the panellists on plastic plates, with a glass of water to rinse their mouths between samples. The sensory assessment was run around 11-12 AM. 


\subsection{Chemical composition of the control and selected samples}

The moisture, ash, fat, protein and crude fibre contents were determined according to AACC methods (American Association of Cereal Chemists, 2000) 15-44A, 08-01, 30-25, 46-11A and 23-10, respectively. The total phenolic compound content was determined according to Karp et al. (2017). The calcium, magnesium, potassium and iron contents were determined using an atomic absorption spectrophotometer (Gupta et al., 2009).

\subsection{Statistical analysis}

A completely randomized design-factorial experiment was followed. The independent variables were the oleaster replacement level $(15 \%, 30 \%$ and $45 \%)$ and active gluten level ( 0 and $3 \%)$, based on the wheat flour content of the formulation. Seven samples including the control (100\% wheat flour), three sponge cakes with $15 \%, 30 \%$ and $45 \%$ of oleaster flour ( 15 OF, 30 OF, 45 OF) and three samples with $15 \%, 30 \%, 45 \%$ of oleaster flour and $3 \%$ gluten (15 OFG, 30 OFG and $45 \mathrm{OFG}$ ), were considered. The textural characteristics of the control and of the best sample were evaluated during the storage time. In the second step, $0,30 \%$, $50 \%$ and $70 \%$ of the sucrose content of the sample selected in the first step were replaced with potassium acesulfame and isomalt and the qualitative characteristics of the samples evaluated. The textural characteristics of the samples with higher quality were evaluated during storage. All the measurements were made in triplicate and the statistical analyses applied using SAS 9.1 software. The Fisher's least significant difference (LSD) was applied to explain the means with 95\% confidence. The statistical analysis of the sensory properties was carried out according to the non-parametric Kruskal-Wallis method (Lane et al., 2016).

\section{Results and discussion}

\subsection{Comparison of the chemical compositions of wheat and oleaster flours}

Oleaster flour had higher ash, fat, crude fibre and total phenolic compound contents than wheat flour (Table 2), the crude fibre and phenolic compound contents of the oleaster flour being more than tenfold those of wheat flour. From the nutritional point of view, there is an inverse association between the consumption of dietary fibre and the risks of cancer, heart disease and type 2 diabetes (Mudgil \& Barak, 2013). The antioxidant properties of the phenolic components have a special effect on the stability of oxidation sensitive components such as lipids (Devi et al., 2014). In a study carried out by Sahan et al. (2013), the ash, protein and fibre contents of two different oleaster samples from Turkey were reported as (2.57 and $1.87 \mathrm{~g} / 100 \mathrm{~g}),(4.49$ and $4.65 \mathrm{~g} / 100 \mathrm{~g})$ and $(30.65$ and $25.44 \mathrm{~g} / 100 \mathrm{~g})$, respectively. The quantities of the chemical components found in the oleaster flour in the present study were relatively similar to those found in other studies and minor differences could be attributed to differences in the oleaster species and in the climatic, geographical and experimental conditions.

Table 2. Proximate composition of the wheat and oleaster flours.

\begin{tabular}{|c|c|c|c|c|c|}
\hline \multirow{2}{*}{ Flours } & Ash & Fat & Protein & Crude fibre & \multirow{2}{*}{$\frac{\text { Total phenolic }}{\text { (mg Gallic acid/100 g) }}$} \\
\hline & \multicolumn{4}{|c|}{ (g/100 g of dry matter) } & \\
\hline Wheat flour & $0.66^{\mathrm{b}} \pm 0.01$ & $0.83^{b} \pm 0.00$ & $9.32^{\mathrm{a}} \pm 0.06$ & $0.69^{\mathrm{b}} \pm 0.08$ & $26.10^{b} \pm 0.6$ \\
\hline Oleaster flour & $2.44^{a} \pm 0.08$ & $4.38^{a} \pm 0.07$ & $6.30^{b} \pm 0.25$ & $10.47^{\mathrm{a}} \pm 1.1$ & $436.60^{\mathrm{a}} \pm 8.9$ \\
\hline
\end{tabular}

Values represent mean \pm standard deviation $(\mathrm{n}=3)$. Different letters in the same column indicate significant difference $(p \leq 0.05)$. 


\subsection{Qualitative characteristics of the sponge cake}

\subsubsection{Apparent density}

Table 3 shows the effects of oleaster flour and gluten on the physical and colour characteristics of the samples. An increase in the percentage of oleaster flour significantly enhanced the sample density $(p \leq 0.05)$ which might be due to dilution of the gluten and of the inappropriate effect of fibre - gluten interaction on gas retention in the batter (Borchani et al., 2011; Belghith Fendri et al., 2016). The high fibre concentration of oleaster flour weakens the gluten matrix, increases gas emission and reduces the specific volume of cereal-based products (Belghith Fendri et al., 2016). Chareonthaikij et al. (2016) observed that fibre containing dough had a low apparent viscosity, and hence the air bubbles in the bread were not protected during baking. Furthermore, the addition of green banana, with a high fibre content, had a negative effect on the specific volume of sponge cakes (Segundo et al., 2017). The samples containing gluten were less dense than samples without due to the positive effect of active gluten on improving gas retention during baking.

The effect of the oleaster-gluten interaction on the physical characteristics of the cakes shown in Table 4, indicates that samples containing oleaster and gluten were more dense than the control; nevertheless, the density of the sample containing $15 \%$ oleaster flour and $3 \%$ gluten was not significantly different from that of the control sample. Therefore, $3 \%$ of gluten can modify the undesirable effect of oleaster flour on cake density, whereas greater oleaster flour contents significantly reduced the volume, even in the presence of gluten.

\subsubsection{Textural characteristics}

Table 3 shows the effects of the oleaster flour and gluten on the textural characteristics of the cakes. Increasing the oleaster replacement level significantly $(p \leq 0.05)$ decreased cake hardness since, due to its disruptive effect on the protein-starch matrix, the presence of fibre in the formulation reduces the hardness of the product (Tudorică et al., 2002). Likewise, Belghith Fendri et al. (2016), found that the addition of pea and broad bean pods to a bread formulation led to a significant decrease in product hardness due to interactions between the gluten and fibre contents. The addition of $3 \%$ gluten to the batter decreased product hardness by increasing air bubble retention. Segundo et al. (2017) found a negative correlation between the specific volume and crumb hardness of a cereal based product. In this study, the samples containing gluten were of less dense and less hard than those without gluten. Therefore, considering the effects of oleaster flour and gluten on hardness, the highest and lowest values for hardness were found, respectively, in the control and in the sponge cake with $45 \%$ of oleaster flour and $3 \%$ of gluten (Table 4 ).

Cohesiveness represents the internal resistance of a food structure. An increase in the oleaster substitution level from $15 \%$ to $45 \%$ significantly $(p \leq 0.05)$ decreased the cohesiveness of the product due to its destructive effect on the three-dimensional structure of the protein (Noorlaila et al., 2017), whereas active gluten improved cohesiveness, due to strengthening of the gluten network integration. Consequently, the addition of gluten with together with oleaster had a significant effect on decreasing the destructive effects of oleaster on the textural properties of the cake. The effect of the oleaster-gluten interaction on cohesiveness indicated that samples containing $45 \%$ of oleaster flour were the least cohesive (Table 4 ).

Springiness decreased as the oleaster replacement level increased. Fibrous compounds have a negative effect on detachment of the starch-protein matrix (Tudorică et al., 2002) and hence the above observation was related to the high fibre content of the oleaster flour and its adverse effect on the integrity of the viscoelastic gluten network. Gluten is the major contributing agent to the elasticity and adhesiveness of a batter (Guadarrama-Lezama et al., 2016). Therefore, active gluten improved the springiness by decreasing the density and strengthening the protein-starch linkages. Thus it has been reported that resistant starch, being a soluble fibre, reduced the springiness of muffins and produced a dense matrix in the product (Baixauli et al., 
2008). In the present study, the least springy sample was that with $45 \%$ of oleaster flour (Table 4 ). Furthermore, at the highest oleaster replacement level, the effect of active gluten on the improvement of springiness decreased.

\subsubsection{Colour}

The $\mathrm{L}^{*}, \mathrm{a}^{*}$ and $\mathrm{b}^{*}$ values represent white-black (from 0 to 100 ), redness- greenness (from -120 to +120 ) and yellowness-blueness (from -120 to +120 ), respectively (Salehi et al., 2016). The effects of the independent variables and their interactions on the colour properties of the crust and crumb are shown in Tables 3 and 4, respectively. For the crust, increasing the oleaster percentage intensified $a^{*}$ and decreased $\mathrm{b}^{*}$ and $\mathrm{L}^{*}$, while gluten increased $\mathrm{b}^{*}$ and $\mathrm{L}^{*}$. Therefore, the oleaster flour increased the crust and crumb colour difference $(\Delta \mathrm{E})$, while the differences in crust colour decreased with the addition of gluten. The surface characteristics of the samples were affected by different parameters such as the ingredients, temperature, baking time, and intensity of the non-enzymatic browning reaction. The crust temperature usually increases above $150{ }^{\circ} \mathrm{C}$, and consequently, the Maillard and caramelization reactions are important factors in the crust colour changes (Borchani et al., 2011; De la Hera et al., 2012). The temperature at the centre of the product does not exceed $100{ }^{\circ} \mathrm{C}$ and the high moisture content at this point prevents the Maillard and caramelization reactions. Therefore, the crumb colour may only be affected by the ingredients in the batter formulation (De la Hera et al., 2012). L* decreased significantly in samples with $45 \%$ of oleaster flour, most probably due to the presence of the carotenoid, phenolic compound and high ash contents of the oleaster flour. A similar observation of the colour properties of the product (increase in $\mathrm{a}^{*}$ and decreases in $\mathrm{b}^{*}$ and $\mathrm{L}^{*}$ ) was reported for the replacement of wheat flour by potato peel powder in a cake formulation (Ben Jeddou et al., 2017). The crumb samples containing $3 \%$ gluten were less red than the others, indicating that gluten was effective in decreasing the effect of oleaster flour on changes in the crust and crumb colours.

Table 3. Individual effects of oleaster flour and gluten on the qualitative characteristics of the cakes.

\begin{tabular}{|c|c|c|c|c|c|c|}
\hline & \multirow{2}{*}{ Quality parameters } & \multicolumn{3}{|c|}{ Oleaster flour replacement (\%) } & \multicolumn{2}{|c|}{ Gluten (\%) } \\
\hline & & 15 & 30 & 45 & 0 & 3 \\
\hline \multirow{4}{*}{$\begin{array}{l}\text { Physical and } \\
\text { Textural }\end{array}$} & Density $\left(\mathrm{g} / \mathrm{cm}^{3}\right)$ & $0.37^{\mathrm{c}} \pm 0.01$ & $0.40^{\mathrm{b}} \pm 0.01$ & $0.43^{\mathrm{a}} \pm 0.02$ & $0.41^{\mathrm{a}} \pm 0.03$ & $0.39^{\mathrm{b}} \pm 0.02$ \\
\hline & Hardness (g) & $\begin{array}{c}276.25^{\mathrm{a}} \pm \\
33.94\end{array}$ & $\begin{array}{c}246.88^{\mathrm{b}} \pm \\
41.70\end{array}$ & $\begin{array}{c}221.75^{c} \pm \\
43.29\end{array}$ & $\begin{array}{c}276.5^{\mathrm{a}} \pm \\
34.28\end{array}$ & $\begin{array}{c}220.08^{\mathrm{b}} \pm \\
31.05\end{array}$ \\
\hline & Cohesiveness & $0.64^{\mathrm{a}} \pm 0.06$ & $0.56^{\mathrm{ab}} \pm 0.01$ & $0.54^{\mathrm{b}} \pm 0.06$ & $0.54^{\mathrm{b}} \pm 0.05$ & $0.62^{\mathrm{a}} \pm 0.06$ \\
\hline & Springiness $(\mathrm{mm})$ & $7.82^{a} \pm 0.10$ & $7.39^{b} \pm 0.18$ & $6.89^{c} \pm 0.23$ & $7.24^{b} \pm 0.48$ & $7.49^{\mathrm{a}} \pm 0.37$ \\
\hline \multirow{5}{*}{ Crust colour } & $\mathrm{a}^{*}$ & $22.82^{\mathrm{c}} \pm 1.26$ & $24.73^{b} \pm 0.20$ & $28.66^{\mathrm{a}} \pm 1.20$ & $25.88^{\mathrm{a}} \pm 2.34$ & $24.92^{\mathrm{a}} \pm 3.22$ \\
\hline & $b^{*}$ & $15.15^{\mathrm{a}} \pm 4.24$ & $7.64^{b} \pm 3.18$ & $5.77^{\mathrm{c}} \pm 2.87$ & $6.95^{b} \pm 4.43$ & $12.09^{\mathrm{a}} \pm 5.08$ \\
\hline & $\mathrm{L}$ & $48.28^{a} \pm 4.13$ & $41.23^{b} \pm 3.53$ & $39.17^{b} \pm 2.31$ & $40.47^{\mathrm{b}} \pm 4.33$ & $45.07^{\mathrm{a}} \pm 5.24$ \\
\hline & $\Delta \mathrm{E}$ & $7.94^{\mathrm{c}} \pm 1.90$ & $13.73^{b} \pm 4.16$ & $17.24^{\mathrm{a}} \pm 3.65$ & $14.77^{\mathrm{a}} \pm 6.03$ & $11.17^{b} \pm 3.41$ \\
\hline & Chroma (C) & $27.62^{\mathrm{ab}} \pm 1.60$ & $26.03^{b} \pm 0.76$ & $29.34^{\mathrm{a}} \pm 1.09$ & $27.14^{\mathrm{a}} \pm 1.77$ & $28.19^{\mathrm{a}} \pm 1.79$ \\
\hline \multirow{5}{*}{ Crumb colour } & $\mathrm{a}^{*}$ & $-1.00^{c} \pm 0.20$ & $0.77^{b} \pm 1.20$ & $5.32^{\mathrm{a}} \pm 0.92$ & $2.24^{\mathrm{a}} \pm 3.16$ & $1.15^{\mathrm{b}} \pm 2.80$ \\
\hline & $b^{*}$ & $26.00^{\mathrm{a}} \pm 1.48$ & $23.03^{b} \pm 0.75$ & $15.88^{c} \pm 0.75$ & $21.02^{\mathrm{a}} \pm 4.56$ & $22.26^{\mathrm{a}} \pm 4.85$ \\
\hline & $\mathrm{L}$ & $60.87^{\mathrm{a}} \pm 1.80$ & $58.32^{\mathrm{a}} \pm 1.76$ & $51.04^{b} \pm 1.31$ & $56.26^{\mathrm{a}} \pm 4.78$ & $57.23^{\mathrm{a}} \pm 4.81$ \\
\hline & $\Delta \mathrm{E}$ & $16.61^{c} \pm 2.53$ & $20.85^{b} \pm 1.85$ & $31.98^{\mathrm{a}} \pm 1.48$ & $24.07^{\mathrm{a}} \pm 7.27$ & $22.22^{\mathrm{a}} \pm 7.30$ \\
\hline & Chroma (C) & $26.02^{\mathrm{a}} \pm 1.48$ & $23.07^{b} \pm 0.75$ & $16.77^{c} \pm 0.46$ & $21.43^{\mathrm{a}} \pm 3.99$ & $22.48^{\mathrm{a}} \pm 4.57$ \\
\hline
\end{tabular}

Values represent the mean \pm standard deviation $(n=3)$. Mean values followed by different letters in the same row indicate significant difference $(p \leq 0.05)$. 
The effects of oleaster flour, active gluten and sucrose replacement with potassium acesulfame and isomalt on the qualitative properties of functional sponge cakes

Kouhanestani, S. B. et al.

Table 4. Effect of the oleaster flour - active gluten interaction on the qualitative attributes of the cakes.

\begin{tabular}{|c|c|c|c|c|c|c|c|c|}
\hline & \multirow{2}{*}{$\begin{array}{c}\text { Quality } \\
\text { parameter }\end{array}$} & \multicolumn{7}{|c|}{ Cake } \\
\hline & & Control & $15 \mathrm{OF}$ & 15 OFG & $30 \mathrm{OF}$ & 30 OFG & $45 \mathrm{OF}$ & 45 OFG \\
\hline \multirow{4}{*}{$\begin{array}{l}\text { Physical } \\
\text { and } \\
\text { Textural }\end{array}$} & Density $\left(\mathrm{g} / \mathrm{cm}^{3}\right)$ & $0.36^{\mathrm{e}} \pm 0.00$ & $0.38^{\mathrm{d}} \pm 0.00$ & $0.36^{\mathrm{e}} \pm 0.00$ & $0.41^{\mathrm{b}} \pm 0.00$ & $0.39^{c} \pm 0.00$ & $0.44^{\mathrm{a}} \pm 0.00$ & $0.41^{\mathrm{b}} \pm 0.00$ \\
\hline & Hardness (g) & $336.5^{\mathrm{a}} \pm 13.44$ & $305.25^{b} \pm 6.01$ & $247.25^{\mathrm{d}} \pm 7.42$ & $265.25^{\mathrm{c}} \pm 57.63$ & $228.5^{\mathrm{d}} \pm 23.33$ & $259^{c} \pm 1.71$ & $184.5^{\mathrm{e}} \pm 8.49$ \\
\hline & Cohesiveness & $0.6^{\mathrm{a}} \pm 0.03$ & $0.6^{\mathrm{ab}} \pm 0.01$ & $0.67^{\mathrm{a}} \pm 0.1$ & $0.52^{\mathrm{bc}} \pm 0.03$ & $0.61^{\mathrm{ab}} \pm 0.04$ & $0.50^{c} \pm 0.02$ & $0.59^{\mathrm{abc}} \pm 0.01$ \\
\hline & Springiness (mm) & $7.7^{\mathrm{ab}} \pm 0.16$ & $7.75^{\mathrm{ab}} \pm 0.08$ & $7.89^{\mathrm{a}} \pm 0.06$ & $7.26^{\mathrm{cd}} \pm 0.11$ & $7.51^{\mathrm{bc}} \pm 0.16$ & $6.70^{\mathrm{e}} \pm 0.04$ & $7.08^{\mathrm{d}} \pm 0.1$ \\
\hline \multirow{10}{*}{$\begin{array}{l}\text { Crust } \\
\text { colour }\end{array}$} & $\mathrm{a}^{*}$ & $23.36^{\mathrm{bc}} \pm 1.86$ & $23.9^{b c} \pm 0.16$ & $21.74^{\mathfrak{c}} \pm 0.21$ & $24.98^{\mathrm{b}} \pm 0.04$ & $24.48^{\mathrm{bc}} \pm 1.29$ & $28.79^{\mathrm{a}} \pm 0.97$ & $28.53^{\mathrm{a}} \pm 1.82$ \\
\hline & $\mathrm{b}^{*}$ & $16.77^{\mathrm{a}} \pm 3.43$ & $12.13^{b} \pm 2.68$ & $18.18^{\mathrm{a}} \pm 3.17$ & $5.18^{\mathrm{e}} \pm 2.24$ & $10.1^{c} \pm 1.08$ & $3.55^{\mathrm{e}} \pm 1.65$ & $7.99^{\mathrm{d}} \pm 1.49$ \\
\hline & $\mathrm{L}$ & $51.22^{\mathrm{a}} \pm 5.4$ & $45.45^{\mathrm{ab}} \pm 2.42$ & $51.12^{\mathrm{a}} \pm 3.64$ & $39.0^{b} \pm 3.99$ & $43.46^{\mathrm{ab}} \pm 1.24$ & $37.64^{b} \pm 1.46$ & $40.64^{\mathrm{b}} \pm 2.23$ \\
\hline & $\Delta \mathrm{E}$ & $00.00^{\mathrm{d}} \pm 00.00$ & $7.59^{c} \pm 2.89$ & $8.29^{c} \pm 1.42$ & $16.96^{\mathrm{ab}} \pm 2.03$ & $10.49^{\mathrm{c}} \pm 8.14$ & $19.76^{\mathrm{a}} \pm 8.38$ & $14.72^{b} \pm 9.74$ \\
\hline & Chroma (C) & $28.88^{\mathrm{ab}} \pm 0.49$ & $28.85^{\mathrm{abc}} \pm 1.35$ & $28.4^{\mathrm{abc}} \pm 1.9$ & $25.56^{\mathrm{c}} \pm 0.50$ & $26.50^{\mathrm{bc}} \pm 0.78$ & $29.02^{\mathrm{ab}} \pm 1.16$ & $29.66^{\mathrm{a}} \pm 1.35$ \\
\hline & $a^{*}$ & $-8.50^{\mathrm{e}} \pm 0.40$ & $-0.89^{d} \pm 0.17$ & $-1.11^{\mathrm{d}} \pm 0.01$ & $1.55^{\mathrm{c}} \pm 0.03$ & $-0.01^{\mathrm{d}} \pm 1.58$ & $6.07^{\mathrm{a}} \pm 0.2$ & $4.57^{b} \pm 0.47$ \\
\hline & $b^{*}$ & $35.82^{\mathrm{a}} \pm 0.14$ & $24.92^{\mathrm{c}} \pm 0.8$ & $27.06^{\mathrm{b}} \pm 1.20$ & $22.84^{\mathrm{d}} \pm 0.05$ & $23.23^{\mathrm{cd}} \pm 1.24$ & $15.28^{\mathrm{e}} \pm 0.45$ & $16.48^{\mathrm{e}} \pm 0.17$ \\
\hline & $\mathrm{L}$ & $71.8^{\mathrm{a}} \pm 1.62$ & $60.32^{b} \pm 0.93$ & $61.4^{\mathrm{b}} \pm 2.76$ & $58.0^{b} \pm 1.75$ & $58.6^{b} \pm 2.62$ & $50.42^{\mathrm{c}} \pm 1.91$ & $51.66^{c} \pm 0.1$ \\
\hline & $\Delta \mathrm{E}$ & $00.00^{\mathrm{d}} \pm 00.00$ & $17.61^{\mathrm{bc}} \pm 0.15$ & $15.61^{\mathrm{c}} \pm 3.89$ & $21.53^{b} \pm 2.24$ & $20.17^{\mathrm{bc}} \pm 1.84$ & $33.08^{a} \pm 0.31$ & $30.89^{9} \pm 1.27$ \\
\hline & Chroma (C) & $36.81^{a} \pm 0.23$ & $24.96^{c} \pm 0.79$ & $27.08^{b} \pm 1.20$ & $22.89^{d} \pm 0.05$ & $23.26^{\mathrm{od}} \pm 1.24$ & $16.44^{\mathrm{e}} \pm 0.33$ & $17.10^{\mathrm{e}} \pm 0.3$ \\
\hline
\end{tabular}

Values represent the mean \pm standard deviation $(n=3)$. Mean values followed by different letters in the same row indicate significant difference $(p \leq 0.05)$. Control: $100 \%$ wheat flour without added gluten. $15 \mathrm{OF}, 30 \mathrm{OF}, 45 \mathrm{OF}: 15 \%, 30 \%$ and $45 \%$, respectively, of the wheat flour was replaced by oleaster flour. $15 \mathrm{OFG}, 30 \mathrm{OFG}, 45 \mathrm{OFG}: 15 \%, 30 \%$ and $45 \%$, respectively, of the wheat flour was replaced by oleaster flour plus the addition of $3 \%$ gluten.

\subsection{Sensory evaluation}

Table 5 shows the results of the sensory evaluation. With respect to the textural characterizations, the highest scores were obtained by $15 \mathrm{OF}$ and $30 \mathrm{OFG}$, with no statistically significant difference from the control sample $(p \leq 0.05)$. All the samples were relatively desirable in terms of the taste and overall acceptance. The high scores obtained for unpleasant aftertaste indicated low aftertaste in the samples, and 30 OFG had no significant difference from the control for this term.

Regarding the qualitative characteristics of the samples (Table 4), 15 OFG and 30 OFG were statistically more similar to each other and to the control. Therefore, according to the results of the instrumental and sensory analyses, the sample containing $30 \%$ of oleaster flour and $3 \%$ of gluten ( 30 OFG) was selected as the best sample with a higher oleaster flour content. It is a functional sponge cake when one considers the higher nutritional values of oleaster flour as compared to those of wheat flour (Table 6), and showed the least significant undesirable changes in the qualitative characteristics as compared to the control.

Table 5. Sensory evaluation of the sponge cakes.

\begin{tabular}{ccccccc}
\hline Sample & Colour & Aroma & Texture & Flavour & $\begin{array}{c}\text { Unpleasant } \\
\text { after-taste }\end{array}$ & $\begin{array}{c}\text { Overall } \\
\text { acceptance }\end{array}$ \\
\hline Control & $4.07^{\mathrm{abc}} \pm 1.33$ & $4.20^{\mathrm{a}} \pm 0.77$ & $4.54^{\mathrm{a}} \pm 0.52$ & $4.33^{\mathrm{a}} \pm 0.72$ & $4.40^{\mathrm{a}} \pm 0.89$ & $4.40^{\mathrm{a}} \pm 0.89$ \\
15 OF & $3.93^{\mathrm{abc}} \pm 1.09$ & $4.20^{\mathrm{a}} \pm 0.86$ & $4.47^{\mathrm{a}} \pm 0.92$ & $4.07^{\mathrm{a}} \pm 0.79$ & $4.20^{\mathrm{ab}} \pm 0.68$ & $4.40^{\mathrm{a}} \pm 0.68$ \\
15 OFG & $3.73^{\mathrm{c}} \pm 1.28$ & $4.20^{\mathrm{a}} \pm 1.08$ & $3.80^{\mathrm{c}} \pm 0.01$ & $4.07^{\mathrm{a}} \pm 1.03$ & $4.13^{\mathrm{ab}} \pm 1.19$ & $4.27^{\mathrm{a}} \pm 1.19$ \\
30 OF & $3.87^{\mathrm{bc}} \pm 1.13$ & $4.07^{\mathrm{a}} \pm 0.88$ & $3.93^{\mathrm{bc}} \pm 0.7$ & $4.07^{\mathrm{a}} \pm 0.79$ & $4.00^{\mathrm{b}} \pm 0.53$ & $4.27^{\mathrm{a}} \pm 0.53$ \\
30 OFG & $4.00^{\mathrm{abc}} \pm 0.93$ & $4.20^{\mathrm{a}} \pm 0.94$ & $4.33^{\mathrm{ab}} \pm 0.82$ & $4.07^{\mathrm{a}} \pm 0.59$ & $4.27^{\mathrm{ab}} \pm 0.70$ & $4.33^{\mathrm{a}} \pm 0.70$ \\
45 OF & $4.40^{\mathrm{a}} \pm 0.91$ & $4.00^{\mathrm{a}} \pm 0.93$ & $3.93^{\mathrm{bc}} \pm 1.03$ & $4.27^{\mathrm{a}} \pm 0.96$ & $4.47^{\mathrm{a}} \pm 0.52$ & $4.40^{\mathrm{a}} \pm 0.52$ \\
45 OFG & $4.27^{\mathrm{ab}} \pm 1.09$ & $4.07^{\mathrm{a}} \pm 1.09$ & $4.13^{\mathrm{bc}} \pm 0.99$ & $4.33^{\mathrm{a}} \pm 0.82$ & $4.13^{\mathrm{ab}} \pm 0.92$ & $4.33^{\mathrm{a}} \pm 0.92$ \\
\hline
\end{tabular}

Values are expressed as the mean \pm standard deviation $(n=15)$. Mean values followed by different letters in each column indicate significant difference $(p \leq 0.05)$. The score range was in the range from 1 to 5 from extremely undesirable to extremely desirable. Control: $100 \%$ wheat flour with no added gluten. $15 \mathrm{OF}, 30 \mathrm{OF}, 45 \mathrm{OF}: 15 \%, 30 \%$ and $45 \%$, respectively, of the wheat flour were replaced by oleaster flour. $15 \mathrm{OFG}$, $30 \mathrm{OFG}, 45 \mathrm{OFG}: 15 \%, 30 \%$ and $45 \%$, respectively, of the wheat flour was replaced by oleaster flour plus the addition of $3 \%$ gluten. 


\subsection{Chemical composition of the selected sample (30 OFG) and the control}

The proximate compositions of the selected and control samples (Table 6), indicated that the moisture, fat, crude fibre, calcium, potassium and total phenolic compound contents of the selected sample were significantly higher than those of the control and the protein content significantly lower. Therefore, the selected sample containing oleaster flour had a higher nutritional value than the control (100\% wheat flour).

Table 6. Proximate compositions of the control and the selected sample.

\begin{tabular}{|ccc|}
\hline Constituent & Control & Selected sample (30 OFG) \\
\hline Moisture $(\%)$ & $19.94^{\mathrm{b}} \pm 0.12$ & $22.54^{\mathrm{a}} \pm 0.06$ \\
\hline Ash $(\mathrm{g} / 100 \mathrm{~g}$ dry matter) & $1.08^{\mathrm{a}} \pm 0.15$ & $1.38^{\mathrm{a}} \pm 0.15$ \\
\hline Fat $(\mathrm{g} / 100 \mathrm{~g}$ dry matter) & $24.15^{\mathrm{b}} \pm 0.58$ & $26.55^{\mathrm{a}} \pm 0.14$ \\
\hline Protein $(\mathrm{g} / 100 \mathrm{~g}$ dry matter) & $13.25^{\mathrm{a}} \pm 0.06$ & $11.91^{\mathrm{b}} \pm 0.31$ \\
\hline Crude fibre $(\mathrm{g} / 100$ g dry matter) & $0.39^{\mathrm{b}} \pm 0.07$ & $0.92^{\mathrm{a}} \pm 0.03$ \\
\hline Calcium $(\mathrm{mg} / 100 \mathrm{~g}$ dry matter) & $33.96^{\mathrm{b}} \pm 12.11$ & $48.09^{\mathrm{a}} \pm 11.52$ \\
\hline Magnesium $(\mathrm{mg} / 100$ g dry matter) & $22.48^{\mathrm{a}} \pm 6.01$ & $23.24^{\mathrm{a}} \pm 4.41$ \\
\hline Potassium $(\mathrm{mg} / 100$ g dry matter) & $154.88^{\mathrm{b}} \pm 34.97$ & $243.02^{\mathrm{a}} \pm 35.03$ \\
\hline Iron $(\mathrm{mg} / 100$ g dry matter) & $4.01^{\mathrm{a}} \pm 1.50$ & $3.99^{\mathrm{a}} \pm 1.3$ \\
\hline Total phenolic compound content & $73.06^{\mathrm{b}} \pm 1.23$ & $112.58^{\mathrm{a}} \pm 3.59$ \\
\hline
\end{tabular}

Values represent mean \pm standard deviation $(\mathrm{n}=3)$. Different letters in the same row indicate significant difference $(p \leq 0.05)$. Control: Sample prepared with $100 \%$ of wheat flour and no added gluten. Selected sample: Sample prepared with $30 \%$ replacement of the wheat flour by oleaster flour plus $3 \%$ gluten.

\subsection{Textural properties of the selected sample ( 30 OFG) and control during storage}

Staling is an undesirable change occurring during storage which is related to starch retrogradation and moisture migration from the centre to the surface of the product (Noorlaila et al., 2017). The effect of treatment-time on the hardness of the samples was significant. The lower hardness of the selected sample on the first day after production was related to the effect of oleaster flour and its fibre composition on detachment of the gluten-starch matrix (Curti et al., 2016). During storage the hardness of both samples increased, but after 14 days of storage, the hardness of the selected sample was significantly lower than that of the control (Figure 1A). The role of fibre in retaining water delays water migration and decreases the effects of storage time on the texture of the product (Belghith Fendri et al., 2016). The findings of the present study are in agreement with the results obtained by Lebesi \& Tzia (2011), who enriched cake with bran and found that dietary fibre significantly delayed staling of the cake. Curti et al. (2016) also reported that the addition of potato fibre to bread softened the crumb during storage and reduced staling.

During the storage period, the internal resistance, integration and cohesiveness of the cereal based products gradually decreased. At low values for cohesiveness, the energy required for the second compression decreases (Baixauli et al., 2008). The reduction in cohesiveness during the first seven days of storage was significant and further storage up to the fourteenth day had no significant effect on the reduction in cohesiveness. The effects of the treatment and time-treatment interaction on cohesiveness were insignificant (Figure 1B) and thus the replacement of wheat flour by the proper percentages of oleaster flour did not significantly change the internal resistance of the cake.

The effect of treatment-time on springiness is shown in (Figure 1C). The springiness of the selected sample decreased significantly $(p \leq 0.05)$ during the first seven days of storage time, but the further reduction in springiness that took place gradually up to day 14 was not statistically significant $(p \leq 0.05)$. At the beginning of the shelf life, there was no significant difference in springiness between the selected and control samples, but on the seventh and fourteenth days of storage, the springiness of the selected sample was much lower than that of the control. This was attributed to a reduction in strength of the gluten network and a weakened of the gluten-starch linkage in the three-dimensional structure of the crumb (Zahn et al., 2013), in agreement 
with the findings of Baixauli et al. (2008), who demonstrated that the springiness of muffins enriched with resistant starch was lower than that of the control during the storage period.
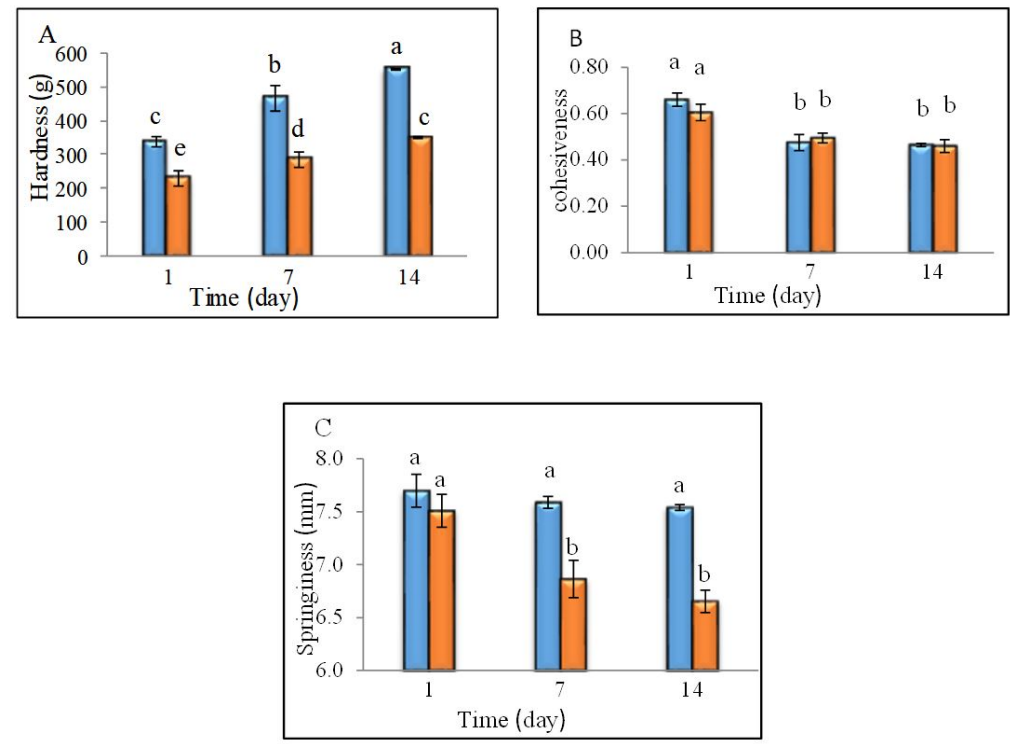

Control: $\square(100 \%$ wheat flour $)$, selected sample: $\square(30 \%$ of oleaster flour and $3 \%$ gluten $)$

Bars with different letters indicate significant differences $(p \leq 0.05)$

Figure 1. Effect of time-treatment on hardness (A), cohesiveness (B) and springiness (C) of the selected sample ( $30 \%$ of oleaster flour and $3 \%$ gluten) and the control (100\% wheat flour with no added gluten) during 14 days of storage.

\subsection{Qualitative characteristics of the low-calorie cakes}

In order to reduce the calories in the selected sample (30 OFG), the sucrose content was partially replaced by potassium acesulfame and isomalt at $0,30,50$ and $70 \%$. Table 7 show the effects of sucrose replacement on the qualitative characteristics of the low-calorie cakes.

\subsubsection{Moisture}

Replacing sucrose with ace $\mathrm{K}$ and isomalt at $30 \%$ decreased the moisture content of the samples, while at higher percentages, the moisture content of the sponge cakes increased significantly $(p \leq 0.05)$. This fact was attributed to the contribution of the hydroxyl group of the sugar alcohol to the binding of water. At low replacement levels, isomalt does not compensate the effect of removing sucrose as a water absorbing ingredient, in maintaining the moisture content of the samples. However, increasing the isomalt content of the batter formulation at the highest sucrose replacement level (70\%) increased the moisture content of the product in a significant manner.

\subsubsection{Apparent density}

The results shown for sample density in Table 7 demonstrated that increasing sucrose replacement enhanced product density. Sucrose delays starch gelatinization, and this is a major contributor to promoting air bubble expansion before fixing the texture of the cake (Gao et al., 2016). Therefore, there are two main reasons for the reduction in volume of low-sugar cakes: 1) the reduction in air bubble stability during baking; and 2) the change in the thermosetting mechanisms due to different interactions between the sweetener, starch and proteins, and the special effect of these on the temperatures of starch gelatinization and protein denaturation (Nourmohammadi \& 
Peighambardoust, 2016). Similar results were obtained by Hao et al. (2016), who found that replacing sucrose by xylitol and erythritol significantly decreased the volume of sponge cakes.

\subsubsection{Textural properties of the low-sugar cakes}

Sucrose replacement by ace $\mathrm{K}$ and isomalt increased the hardness and decreased the cohesiveness of the samples as compared to the control sample (30 OFG). The denser structure of low-calorie cakes, caused by inappropriate air bubble expansion during baking, is the main reason affecting their hardness (Ronda et al., 2005). The interactions between sweeteners and starch and the changes in batter viscosity also affected cake hardness (Nourmohammadi \& Peighambardoust, 2016). Thus Hao et al. (2016) replaced sucrose by polyols in cake formulations and found that replacement of the sucrose by xylitol and erythritol increased cake hardness. The low sugar sponge cakes had a denser texture and less cohesiveness as compared to the control because of improper air bubble distribution. Martínez-Cervera et al. (2014) also reported a reduction in the cohesiveness of muffins when the sucrose content was replaced by sorbitol, maltitol and isomalt.

No significant changes were observed in the springiness of the low-calorie cakes as compared to the control in agreement with the findings of Martínez-Cervera et al. (2014), who substituted the sucrose content of muffins by maltitol.

\subsubsection{Colour}

Table 7 shows the colour properties of the samples. In the crust, a* decreased as compared to the control in cakes with $50 \%$ and $70 \%$ sucrose replacement. This could be related to the role of sucrose in the Maillard and caramelization reactions (Ronda et al., 2005). The $b^{*}$ and $L^{*}$ values increased and decreased, respectively, as compared to the control, and the $\mathrm{a}^{*}$ and $\mathrm{b}^{*}$ values of the crumb also increased. Consequently it can be deduced that the overall appearance of the samples containing dietary sugars was darker than that of the control, which was more evident at the surface. Similarly, the addition of fructose and oligofructose to cake formulations was shown to increased crust darkness (Nourmohammadi \& Peighambardoust, 2016). As to the changes in crumb colour, the present findings correspond to those of Martínez-Cervera et al. (2012) who replaced the sucrose in muffins with a mixture of polydextrose and sucralose.

Table 7. Effect of potassium acesulfame - isomalt on the qualitative characteristics of the sponge cakes (30 OFG*).

\begin{tabular}{|c|c|c|c|c|c|}
\hline & \multirow{2}{*}{ Quality parameter } & \multicolumn{4}{|c|}{ Replacement level of sucrose with ace $K$ and isomalt (\%) } \\
\hline & & $\mathbf{0}$ & 30 & 50 & 70 \\
\hline \multirow{5}{*}{$\begin{array}{l}\text { Texture } \\
\text { and } \\
\text { physical }\end{array}$} & Moisture content $(\%)$ & $22.54^{b} \pm 0.06$ & $22.19^{c} \pm 0.24$ & $22.51^{b} \pm 0.10$ & $22.85^{\mathrm{a}} \pm 0.13$ \\
\hline & Density $\left(\mathrm{g} / \mathrm{cm}^{3}\right)$ & $0.39^{\mathrm{d}} \pm 0.00$ & $0.42^{\mathrm{c}} \pm 0.00$ & $0.45^{\mathrm{b}} \pm 0.00$ & $0.55^{\mathrm{a}} \pm 0.00$ \\
\hline & Hardness (g) & $228.5^{\mathrm{b}} \pm 23.33$ & $312.75^{\mathrm{a}} \pm 6.72$ & $315.75^{\mathrm{a}} \pm 7.42$ & $364.0^{\mathrm{a}} \pm 24.75$ \\
\hline & Cohesiveness & $0.61^{\mathrm{a}} \pm 0.04$ & $0.57^{\mathrm{b}} \pm 0.01$ & $0.56^{\mathrm{bc}} \pm 0.04$ & $0.53^{c} \pm 0.04$ \\
\hline & Springiness $(\mathrm{mm})$ & $7.51^{\mathrm{a}} \pm 0.16$ & $7.16^{\mathrm{a}} \pm 0.31$ & $6.66^{\mathrm{a}} \pm 0.47$ & $6.11^{\mathrm{a}} \pm 0.66$ \\
\hline \multirow{5}{*}{$\begin{array}{l}\text { Crust } \\
\text { colour }\end{array}$} & $\mathrm{a}^{*}$ & $24.48^{\mathrm{a}} \pm 1.29$ & $23.24^{\mathrm{a}} \pm 1.07$ & $21.40^{b} \pm 0.09$ & $18.32^{\mathrm{c}} \pm 0.42$ \\
\hline & $b^{*}$ & $10.10^{\mathrm{b}} \pm 1.08$ & $12.76^{\mathrm{a}} \pm 0.83$ & $12.92^{\mathrm{a}} \pm 1.37$ & $13.44^{\mathrm{a}} \pm 1.31$ \\
\hline & $\mathrm{L}$ & $43.46^{a} \pm 1.24$ & $36.60^{b} \pm 1.57$ & $36.63^{b} \pm 1.17$ & $31.05^{c} \pm 0.89$ \\
\hline & $\Delta \mathrm{E}$ & $00.00^{c} \pm 00.0$ & $7.47^{b} \pm 0.42$ & $8.05^{b} \pm 0.30$ & $14.27^{\mathrm{a}} \pm 0.01$ \\
\hline & Chroma (C) & $26.50^{\mathrm{a}} \pm 0.78$ & $26.51^{a} \pm 0.53$ & $25.01^{\mathrm{a}} \pm 0.63$ & $22.74^{b} \pm 0.43$ \\
\hline \multirow{5}{*}{$\begin{array}{l}\text { Crumb } \\
\text { colour }\end{array}$} & $a^{*}$ & $0.01^{\mathrm{d}} \pm 0.16$ & $1.11^{\mathrm{c}} \pm 0.14$ & $2.02^{b} \pm 0.12$ & $4.55^{\mathrm{a}} \pm 0.05$ \\
\hline & $b^{*}$ & $23.23^{b} \pm 1.24$ & $33.99^{\mathrm{a}} \pm 1.99$ & $34.25^{\mathrm{a}} \pm 1.51$ & $35.31^{\mathrm{a}} \pm 1.73$ \\
\hline & $\mathrm{L}$ & $58.60^{\mathrm{a}} \pm 2.62$ & $56.59^{a} \pm 1.61$ & $54.88^{\mathrm{a}} \pm 1.27$ & $54.22^{\mathrm{a}} \pm 1.47$ \\
\hline & $\Delta \mathrm{E}$ & $00.00^{b} \pm 00.00$ & $11.13^{a} \pm 2.79$ & $11.88^{\mathrm{a}} \pm 0.92$ & $13.83^{\mathrm{a}} \pm 1.81$ \\
\hline & Chroma (C) & $23.26^{\mathrm{b}} \pm 1.24$ & $34.01^{\mathrm{a}} \pm 1.98$ & $34.31^{\mathrm{a}} \pm 1.50$ & $35.36^{\mathrm{a}} \pm 0.85$ \\
\hline
\end{tabular}

Values represent the mean \pm standard deviation $(\mathrm{n}=3)$. Different letters in the same row indicate significant difference $(p \leq 0.05) .0,30,50$ and $70: 0 \%, 30 \%, 50 \%$ and $70 \%$ of the sucrose content in $30 \mathrm{OFG}$ was replaced by ace $\mathrm{K}$ - isomalt, respectively. *30 OFG (sample selected in previous step): Sample prepared with 30\% replacement of wheat flour by oleaster flour plus 3\% of gluten. 


\subsection{Sensory evaluation of the low-calorie cakes}

In the sensory evaluation, the sample with $70 \%$ sucrose replacement was eliminated due to its inappropriate appearance and low volume. The other samples $(0,30 \%$ and $50 \%$ sucrose replacement) were evaluated and compared. Figure 2 shows that in terms of colour, odour and texture, all three samples were favourable. In terms of taste and unpleasant aftertaste, the sample with $50 \%$ sucrose replacement was more desirable than the control, and in terms of overall acceptance, the samples with $30 \%$ and $50 \%$ replacement were more desirable than the control. Considering the presence of monosaccharide in the oleaster fruit, it was assumed that the partial substitution of sucrose in the cake formulation had a positive effect on the desirability of low-calorie sponge cakes.

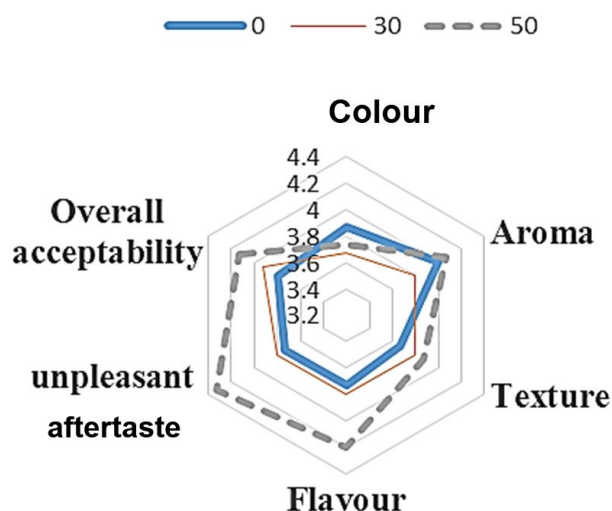

Figure 2. Sensory evaluation of low-calorie cakes. 0,30 and $50: 0 \%, 30 \%$ and $50 \%$ of the sucrose content in the 30 OFG* sample was replaced by ace K-isomalt. *30 OFG: Sample with 30\% of oleaster flour and 3\% of gluten.

\subsection{Textural properties of low-calorie cakes during storage}

The effects of time-treatment on the textural characteristics of sponge cakes made with wheat and oleaster flours with different percentages of sugar replacement are shown in Figure 3. The hardness significantly increased during the shelf life and the low-calorie samples became harder than their control counterparts (Figure 3A). The porous structure and starch retrogradation are proposed as the main factors affecting cake hardness. Furthermore, the water binding capacity of sugar alcohols and their interaction with starch supposedly affect the rate of increase of hardness of the product (Ronda et al., 2005).

Product cohesiveness gradually decreased during the storage time with no statistically significant differences $(p \leq 0.05)$ between the control and the other samples (Figure 3B). At the beginning of the shelf life, the springiness of the cake with $50 \%$ sucrose replacement was significantly lower than that of the control (Figure 3C), which might have been due to the effect of the sweeteners on the change in volume and thermosetting mechanism.

Although, the springiness of the control was greater than the values found for the sugar replaced products at zero time, the springiness of all the samples gradually reduced during the storage time, but the rate of springiness reduction was significantly lower in the low calorie cakes than in the control. Thus, after seven days of storage, the values for springiness of the samples were not significantly different.

According to the results obtained in the textural and sensory analyses, the samples with $30 \%$ and $50 \%$ sucrose replacement were statistically similar in terms of hardness, cohesiveness, springiness and overall acceptance. With respect to the nutritional context, the cake with $50 \%$ sucrose replacement showed the least calories, while from the technological point of view, the cake with $30 \%$ sucrose replacement showed a larger volume and was more desirable. 

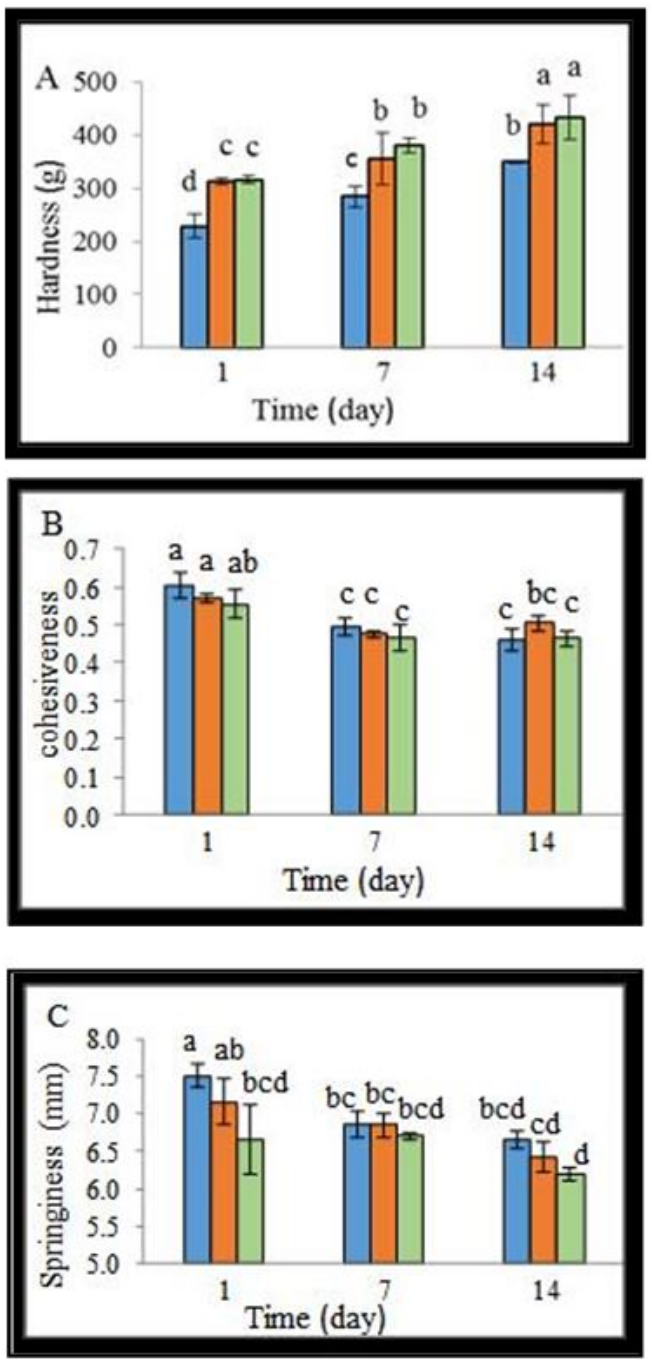

0\%: $\square$ 30\%: $\square 50 \%: \square: 0 \%, 30 \%$ and $50 \%$ of the sucrose content of the 30 OFG* sample was replaced by ace K-isomalt.

Figure 3. The effects of time-treatment on hardness (A), cohesiveness (B) and springiness (C) of the low-calorie cakes during 14 days of storage. ${ }^{*} 30$ OFG: Sample with 30\% of oleaster flour and 3\% of gluten. Bars with different letter indicate significant difference $(p \leq 0.05)$.

\section{Conclusion}

The oleaster fruit with its floury structure, sweet taste and high nutritional value is a suitable ingredient for food products, especially for cereal based products. In the present research, the effects of oleaster flour and active gluten on the quality and nutritional characteristics of sponge cakes were evaluated. The replacement of wheat flour by oleaster flour increased the density and decreased the hardness, cohesiveness and springiness of the sponge cakes. However, the active gluten decreased the density and hardness and increased the springiness and cohesiveness of the samples by modifying the negative effects of the oleaster flour on the texture of the sponge cakes. The sponge cake with $30 \%$ of oleaster flour and $3 \%$ gluten (30 OFG) was selected as the best sample, due to the similarity of its qualitative characteristics with those of the control sample ( $100 \%$ wheat flour). The fat, crude fibre, calcium, potassium and total phenolic compound contents of the selected sample ( $30 \mathrm{OFG}$ ) were considerably higher than those of the control. 
Replacing the sucrose with ace $\mathrm{k}$ and isomalt in the sample with $30 \%$ of oleaster flour and $3 \%$ gluten increased the hardness and density and decreased the cohesiveness but did not affect springiness. However, $30 \%$ sucrose replacement did not significantly affect the qualitative properties of the sample. Therefore, a sponge cake containing 30\% oleaster flour and $3 \%$ gluten with $30 \%$ of the sucrose content replaced by ace $\mathrm{k}$ and isomalt was selected as the best sample with respect to the qualitative properties, with a low calorie content and greater nutritional value and desirability.

\section{References}

Abizov, E. A., Tolkachev, O. N., Maltsev, S. D., \& Abizova, V. (2008). Composition of biologically active substances isolated from the fruits of Russian olive (Elaeagnus angustifolia) introduced in the European part of Russia. Pharmaceutical Chemistry Journal, 42(12), 696-698. http://dx.doi.org/10.1007/s11094-009-0203-5

American Association of Cereal Chemists - AACC. (2000). Approved methods of the American Association of Cereal Chemists (10th ed.). Washington: AACC.

Ayaz, F. A., \& Bertoft, E. (2001). Sugar and phenolic acid composition of stored commercial oleaster fruit. Journal of Food Composition and Analysis, 14(5), 505-511. http://dx.doi.org/10.1006/jfca.2001.1004

Baixauli, R., Salvador, A., \& Fiszman, S. M. (2008). Textural and color changes during storage and sensory shelf life of muffins containing resistant starch. European Food Research and Technology, 226(3), 523-530. http://dx.doi.org/10.1007/s00217-0070565-4

Belghith Fendri, L., Chaari, F., Maaloul, M., Kallel, F., Abdelkafi, L., Ellouz Chaabouni, S., \& Ghribi-Aydi, D. (2016). Wheat bread enrichment by pea and broad bean pods fibers: Effect on dough rheology and bread quality. Lebensmittel-Wissenschaft + Technologie, 73, 584-591. http://dx.doi.org/10.1016/j.Iwt.2016.06.070

Ben Jeddou, K., Bouaziz, F., Zouari-Ellouzi, S., Chaari, F., Ellouz-Chaabouni, S., Ellouz-Ghorbel, R., \& Nouri-Ellouz, O. (2017). Improvement of texture and sensory properties of cakes by addition of potato peel powder with high level of dietary fiber and protein. Food Chemistry, 217, 668-677. PMid:27664685. http://dx.doi.org/10.1016/j.foodchem.2016.08.081

Bigne, F., Puppo, M. C., \& Ferrero, C. (2016). Fiber enrichment of wheat flour with mesquite (Prosopis spp.): Effect on bread making performance and staling. Lebensmittel-Wissenschaft + Technologie, 65, 1008-1016. http://dx.doi.org/10.1016/j.Iwt.2015.09.028

Borchani, C., Masmoudi, M., Besbes, S., Attia, H., Deroanne, C., \& Blecker, C. (2011). Effect of date flesh fiber concentrate addition on dough performance and bread quality. Journal of Texture Studies, 42(4), 300-308. http://dx.doi.org/10.1111/j.17454603.2010.00278.x

Çakmakçı, S., Topdaş, E. F., Kalın, P., Han, H., Şekerci, P., P. Köse, L., \& Gülçin, İ. (2015). Antioxidant capacity and functionality of oleaster (Elaeagnus angustifolia L.) flour and crust in a new kind of fruity ice cream. International Journal of Food Science \& Technology, 50(2), 472-481. http://dx.doi.org/10.1111/ijfs.12637

Chareonthaikij, P., Uan-On, T., \& Prinyawiwatkul, W. (2016). Effects of pineapple pomace fiber on physicochemical properties of composite flour and dough, and consumer acceptance of fiber-enriched wheat bread. International Journal of Food Science \& Technology, 51(5), 1120-1129. http://dx.doi.org/10.1111/ijfs.13072

Curti, E., Carini, E., Diantom, A., \& Vittadini, E. (2016). The use of potato fiber to improve bread physico-chemical properties during storage. Food Chemistry, 195, 64-70. PMid:26575713. http://dx.doi.org/10.1016/j.foodchem.2015.03.092

De la Hera, E., Ruiz-París, E., Oliete, B., \& Gómez, M. (2012). Studies of the quality of cakes made with wheat-lentil composite flours. Lebensmittel-Wissenschaft + Technologie, 49(1), 48-54. http://dx.doi.org/10.1016/j.lwt.2012.05.009

Devi, P. B., Vijayabharathi, R., Sathyabama, S., Malleshi, N. G., \& Priyadarisini, V. B. (2014). Health benefits of finger millet (Eleusine coracana L.) polyphenols and dietary fiber: A review. Journal of Food Science and Technology, 51(6), 1021-1040. PMid:24876635. http://dx.doi.org/10.1007/s13197-011-0584-9

Farzi, M., Saffari, M. M., \& Emam-Djomeh, Z. (2015). Effects of sugar, starch and HPMC concentrations on textural properties of reduced-sugar sponge cakes. Journal of Food Science and Technology, 52(1), 444-450. http://dx.doi.org/10.1007/s13197-0130965-3

Gao, J., Brennan, M. A., Mason, S. L., \& Brennan, C. S. (2016). Effect of sugar replacement with stevianna and inulin on the texture and predictive glycemic response of muffins. International Journal of Food Science \& Technology, 51(9), 1979-1987. http://dx.doi.org/10.1111/ijfs.13143

Grembecka, M. (2015). Sugar alcohols: Their role in the modern world of sweeteners: A review. European Food Research and Technology, 241(1), 1-14. http://dx.doi.org/10.1007/s00217-015-2437-7

Guadarrama-Lezama, A. Y., Carrillo-Navas, H., Pérez-Alonso, C., Vernon-Carter, E. J., \& Alvarez-Ramirez, J. (2016). Thermal and rheological properties of sponge cake batters and texture and microstructural characteristics of sponge cake made with native corn starch in partial or total replacement of wheat flour. Lebensmittel-Wissenschaft + Technologie, 70, 46-54. http://dx.doi.org/10.1016/j.lwt.2016.02.031

Gupta, M., Bawa, A. S., \& Semwal, A. D. (2009). Effect of barley flour incorporation on the instrumental texture of sponge cake. International Journal of Food Properties, 12(1), 243-251. http://dx.doi.org/10.1080/10942910802312082 
The effects of oleaster flour, active gluten and sucrose replacement with potassium acesulfame and isomalt on the qualitative properties of functional sponge cakes

Kouhanestani, S. B. et al.

Gürbüz, I., Ustun, O., Yesilada, E., Sezik, E., \& Kutsal, O. (2003). Anti-ulcerogenic activity of some plants used as folk remedy in Turkey. Journal of Ethnopharmacology, 88(1), 93-97. PMid:12902057. http://dx.doi.org/10.1016/S0378-8741(03)00174-0

Hao, Y., Wang, F., Huang, W., Tang, X., Zou, Q., Li, Z., \& Ogawa, A. (2016). Sucrose substitution by polyols in sponge cake and their effects on the foaming and thermal properties of egg protein. Food Hydrocolloids, 57, 153-159.

http://dx.doi.org/10.1016/j.foodhyd.2016.01.006

Hosseinzadeh, H., Ramezani, M., \& Namjo, N. (2003). Muscle relaxant activity of Elaeagnus angustifolia L. fruit seeds in mice. Journal of Ethnopharmacology, 84(2-3), 275-278. PMid:12648826. http://dx.doi.org/10.1016/S0378-8741(02)00331-8

Karp, S., Wyrwisz, J., Kurek, M. A., \& Wierzbicka, A. (2017). Combined use of cocoa dietary fiber and steviol glycosides in lowcalorie muffins production. International Journal of Food Science \& Technology, 52(4), 944-953.

http://dx.doi.org/10.1111/ijfs.13358

Kendall, C. W., Esfahani, A. J. A., \& Jenkins, D. (2010). The link between dietary fiber and human health. Food Hydrocolloids, 24(1), 42-48. http://dx.doi.org/10.1016/j.foodhyd.2009.08.002

Kim, J. H., Lee, H. J., Lee, H., Lim, E., Imm, J., \& Suh, H. J. (2012). Physical and sensory characteristics of fibre-enriched sponge cakes made with Opuntia humifusa. Lebensmittel-Wissenschaft + Technologie, 47(2), 478-484.

http://dx.doi.org/10.1016/j.lwt.2012.02.011

Lane, K. E., Li, W., Smith, C. J., \& Derbyshire, E. J. (2016). The development of vegetarian omega-3 oil in water Nano emulsions suitable for integration into functional food products. Journal of Functional Foods, 23, 306-314.

http://dx.doi.org/10.1016/j.jff.2016.02.043

Lebesi, M., \& Tzia, C. (2011). Effect of the addition of different dietary fiber and edible cereal bran sources on the baking and sensory characteristics of cupcakes. Food and Bioprocess Technology, 4(5), 710-722. http://dx.doi.org/10.1007/s11947-0090181-3

Lipinski, G. R., \& Hanger, L. Y. (2001). Acesulfame K. In L. O. Nabors (Ed.), Alternative sweeteners (3rd ed.). New York: Marcel Dekker.

Martínez-Cervera, S., Salvador, A., \& Sanz, T. (2014). Comparison of different polyols as total sucrose replacers in muffins: Thermal, rheological, texture and acceptability properties. Food Hydrocolloids, 35, 1-8.

http://dx.doi.org/10.1016/j.foodhyd.2013.07.016

Martínez-Cervera, S., Sanz, T., Salvador, A., \& Fiszman, S. M. (2012). Rheological, textural and sensorial properties of lowsucrose muffins reformulated with sucralose/polydextrose. Lebensmittel-Wissenschaft + Technologie, 45(2), 213-220. http://dx.doi.org/10.1016/j.Iwt.2011.08.001

Moza, J., \& Gujral, H. S. (2017). Influence of barley non-starchy polysaccharides on selected quality attributes of sponge cakes. Lebensmittel-Wissenschaft + Technologie, 85, 252-261. http://dx.doi.org/10.1016/j.Iwt.2017.07.024

Mudgil, D., \& Barak, S. (2013). Composition, properties and health benefits of indigestible carbohydrate polymers as dietary fiber: A review. International Journal of Biological Macromolecules, 61, 1-6. PMid:23831534.

http://dx.doi.org/10.1016/j.ijbiomac.2013.06.044

Noorlaila, A., Hasanah, H. N., Yusoff, A., Sarijo, S. H., \& Asmeda, R. (2017). Effects of xanthan gum and HPMC on physicochemical and microstructure properties of sponge cakes during storage. Journal of Food Science and Technology, 54(11), 3532-3542. PMid:29051648. http://dx.doi.org/10.1007/s13197-017-2810-6

Nourmohammadi, E., \& Peighambardoust, S. H. (2016). New concept in reduced-calorie sponge cake production by xylitol and oligofructose. Journal of Food Quality, 39(6), 627-633. http://dx.doi.org/10.1111/jfq.12233

Öztürk, H. İ., Aydın, S., Sözeri, D., Demirci, T., Sert, D., \& Akın, N. (2018). Fortification of set-type yoghurts with Elaeagnus angustifolia L. flours: Effects on physicochemical, textural, and microstructural characteristics. Lebensmittel-Wissenschaft + Technologie, 90, 620-629. http://dx.doi.org/10.1016/j.Iwt.2018.01.012

Pourafshar, S., Rosentrater, K. A., \& Krishnan, P. G. (2015). Using alternative flours as partial replacement of barbari bread formulation (traditional Iranian bread). Journal of Food Science and Technology, 52(9), 5691-5699. PMid:26344982. http://dx.doi.org/10.1007/s13197-014-1640-z

Ramezani, M., Hosseinzadeh, H., \& Daneshmand, N. (2001). Antinociceptive effect of Elaeagnus angustifolia fruit seeds in mice. Fitoterapia, 72(3), 255-262. PMid:11295301. http://dx.doi.org/10.1016/S0367-326X(00)00290-2

Ronda, F., Gomez, M., Blanco, C., \& Caballero, P. (2005). Effects of polyols and non-digestible oligosaccharides on the quality of sugar-free sponge cakes. Food Chemistry, 90(4), 549-555. http://dx.doi.org/10.1016/j.foodchem.2004.05.023

Sahan, Y., Dundar, A. N., Aydin, E., Kilci, A., Dulger, D., Kaplan, F. B., Gocmen, D., \& Celik, G. (2013). Characteristics of cookies supplemented with oleaster (Elaeagnus angustifolia L.) flour, physicochemical, sensorial and textural properties. The Journal of Agricultural Science, 5(2), 160-168. http://dx.doi.org/10.5539/jas.v5n2p160

Salehi, F., Kashaninejad, M., Asadi, F., \& Najafi, A. (2016). Improvement of quality attributes of sponge cake using infrared dried button mushroom. Journal of Food Science and Technology, 53(3), 1418-1423. PMid:27570266. http://dx.doi.org/10.1007/s13197-015-2165-9

Sarraf, M., Sani, A. M., \& Atash, M. M. S. (2017). Physicochemical, organoleptic characteristics and image analysis of the doughnut enriched with oleaster flour. Journal of Food Processing and Preservation, 41(4), e13021. http://dx.doi.org/10.1111/jfpp.13021 
The effects of oleaster flour, active gluten and sucrose replacement with potassium acesulfame and isomalt on the qualitative properties of functional sponge cakes

Kouhanestani, S. B. et al.

Segundo, C., Roman, L., Gomez, M., \& Martinez, M. M. (2017). Mechanically fractionated flour isolated from green bananas (M. cavendishii var. nanica) as a tool to increase the dietary fiber and phytochemical bioactivity of layer and sponge cakes. Food Chemistry, 219, 240-248. PMid:27765223. http://dx.doi.org/10.1016/j.foodchem.2016.09.143

Tudorică, C. M., Kuri, V., \& Brennan, C. S. (2002). Nutritional and physicochemical Characteristics of dietary fiber enriched pasta. Journal of Agricultural and Food Chemistry, 50(2), 347-356. PMid:11782206. http://dx.doi.org/10.1021/jf0106953

Zahn, S., Forker, A., Krügel, L., \& Rohm, H. (2013). Combined use of rebaudioside A and fibers for partial sucrose replacement in muffins. Lebensmittel-Wissenschaft + Technologie, 50(2), 695-701. http://dx.doi.org/10.1016/j.Iwt.2012.07.026

Funding: No funding was received for present research. It is results of Mrs. Babashahi Kouhanestani thesis that was performed in Islamic Azad University, Isfahan (Khorasgan) Branch under the supervision of

Dr. Abbasi. 